\title{
Evaluation of Buffalo (Bubalus bubalis) Oocyte Protein Content at Different Stages of Maturation
}

\author{
Raghvendra Kumar* and Shalini Jaswal \\ ${ }^{1}$ Animal Biotechnology Centre, ICAR-National Dairy Research Institute Karnal, \\ Haryana 132001, India \\ *Corresponding author
}

K e y w o r d s
Oocyte, Protein
Content, Oocyte
Maturation, in vitro
maturation, in vivo
maturation, Zona
Pellucida

A B S T R A C T
The protein content of buffalo oocyte was estimated using Bradford assay. The sample (oocyte) size was five hundred in a technical replicate. Each group were of different stages of maturation and contained of four technical replicate. These stages were immature zonapellucida free oocyte (IZP'), immature with zonapellucida $\left(\mathrm{IZP}^{+}\right)$, in vitro mature stage with zonapellucida (IVITMZP ${ }^{+}$) and in vivo matured with zonapellucida $\left(\right.$ IVIVZP $^{+}$). The mean protein content of oocyte groups were93.72 \pm 2.76 , $107.14 \pm 3.79,110.04 \pm 3.46,116.11 \pm 3.77 \mathrm{ng} /$ oocyte respectively for IZP, $\mathrm{IZP}^{+}$, IVITMZP $^{+}$, IVIVZP $^{+}$groups respectively. Protein content was highest in in vivo matured oocytes per oocyte. From this study, it was estimated that approximately $13 \%$ of proteins were found in zonapellucida of immature oocyte. Also it was observed, that proteins content in in vivo matured group was higher as compared to in vitro matured group. This variation in protein content is a function of halt and resumption of meiosis during the progression of maturational stages.

\section{Introduction}

Protein based research have potential focus on differential protein study to discover novel protein and their role in various maturational stages of mammalian oocyte. Level of protein in these maturation stages can illustrate different levels of cellular metabolism. So to carry out these experiments adequate number of oocyte is needed for different experimental set up which is vital to be pictured. Since the oocyte contains different stage of progression of growing, grown and eventually mature to competent. It takes long time to accumulate large number of oocyte due to limited supply of ovary from slaughter house. Oocyte proteins are also prone to proteomic degradation. It should be clear which buffer is best suited for extraction of proteins from these germ cells. Methods of protein 
estimation should also be optimised, so the recovery of maximum possible protein can be performed and studied. However, Abattoir house animals are of heterogeneous groups thus oocyte recovered from these differ in qualities. For instance oocyte differs in quality by maternal nutrition, environmental stress, ovarian issues, follicular fluid composition, steroids, intercellular communication, disease and different genetic background etc. Thus variation arises due to recovery of protein from these heterogeneous qualities of ovaries. So from an overall pool of oocyte we can get normalised value of protein content that may be close to true value of protein content in oocyte. Oocyte protein content varies in different mammalian species since, the size of oocytes reported to change with the change in species and of course represents different metabolic state. In view of this, current study was carried out to provide a numerical estimate of protein content in buffalo oocyte.

\section{Materials and Methods}

Oocyte source buffalo ovaries were obtained from nearby abbatoir house Ghazipur, New Delhi it was maintained in antibiotics-fortified warm saline at $32-38{ }^{\circ} \mathrm{C}$ with streptomycin $(500 \mu \mathrm{g} / \mathrm{ml})$. Ovaries were subjected to three times washing in normal saline followed by aspiration in aspiration medium and selection was performed under zoom stereo microscope. Here morphologically screened oocytes were divided into unexpanded cumulus oocyte complex $\left(\mathrm{COC}_{\mathrm{S}}\right)$ and expanded cumulus oocyte complexes. Unexpanded $\mathrm{COC}_{\mathrm{S}}$ were immature and those with expanded $\mathrm{COC}_{S}$ were in vivo mature. From the unexpanded $\mathrm{COC}_{S}$ three groups were made which is described as follows. Immature ZP free oocytes (Group1) were made by removing zonapellucida with enzyme Pronase $(0.5 \mathrm{mg} / \mathrm{ml})$. ZP enclosed cumulus free immature oocyte (Group 2). In vitro matured $\mathrm{ZP}$ enclosed cumulus free oocytes were made after in vitro maturation in IVM media for $24 \mathrm{hr}$. (Group 3). The expanded $\mathrm{COC}_{\text {si.e.in vivo matured } \mathrm{ZP}}$ enclosed were considered as Group 4. For the preparation of these groups Hyaluronidase $(0.75 \mathrm{mg} / \mathrm{ml})$ was used for cumulus mass removal. During the collection process these oocytes were washed 3 times in $\mathrm{Ca}^{++}$and $\mathrm{Mg}^{++}$free DPB S medium for removal of any extra cumulus remained. At the time of storage oocytes at $-80{ }^{\circ} \mathrm{C}$ (Cryopreservation) in $\mathrm{Ca}^{++}$and $\mathrm{Mg}^{++}$free DPBS protease inhibitor $(1 \% \mathrm{v} / \mathrm{v})$ cocktail was used to prevent further degradation of proteins. Appropriate volume was done using vacuum concentrator at $4^{\circ} \mathrm{C}$.After getting sufficient numbers of oocyte (500) for every technical replicates (4) in each group (Fig. 1) protein extraction was done. For this RIPA (Radio Immuno Precipitation Assay) buffer was used for extraction of proteins at $4^{\circ} \mathrm{C}$ on ice. Sonication $(30 \%$ amplitude for four cycles with $30 \mathrm{~s}$ on $/ 5 \mathrm{~s}$ off pulses.) was performed immediately so that integral proteins of membrane may come in solution. Protein present in extraction buffer was checked in zoom stereo microscope to see whether cells are lysed or not. Protein solution was then centrifuged at $12000 \mathrm{~g}$ and supernatant was taken for protein quantification was performed using Bradford protein assay (Bradford. 1976) using BSA as protein standard and absorbance measured at $595 \mathrm{~nm}$.

\section{Statistical analysis}

Statistical analysis of data was performed using SPSS software (Version 21)and Tukey test was applied for checking the significance difference among least square means of different groups.

\section{Results and Discussion}

Since the oocyte are spherical in shape so the complete removal of cumulus cells were confirmed under zoom stereo microscope 
(Fig. 2). SDS PAGE was run to check whether protein estimation is according to band pattern obtained (Fig. 2) Estimation of proteins results is depicted into table 1 and statistically mentioned in Fig. 3.

Protein content was highest in in vivo matured oocytes per oocyte and least in zona free oocyte. Here, we observed approximately $13 \%$ of proteins were found in zonapellucida of immature oocyte. Also it was observed, that proteins content in in vivo matured group was higher as compared to in vitro matured group but the differences were not significant. The overall range of proteins was observed between 90-120 ng/oocyte.

Protein content in oocyte is essential for key processes like fertilisation and development of embryo. Proteome and its functions decide phenotype and developmental potential of oocyte. During the different oocyte maturation, numerous changes take place through dynamic variations of protein composition along with cumulus oocyte complex (Wang et al., 2010). Despite the fact that ovary we obtain from abattoir, comes from heterogeneous group of population, thus oocyte recovered from these ovary may possess mix of optimal and suboptimal function. Age, race, breed diet diseased conditioned may lead to different protein content. For the first time in bovine mean protein content of oocyte estimated value was126ng/oocyte (Grealy et al., 1996). Notable reports from Thompson et al., 1998inbovine ZP free mature oocytes estimated 122 $\pm 7.8 \mathrm{ng} /$ oocyte. But in our report in buffalo we found $93.72 \pm 2.76$ ng/oocyte in zona free immature oocyte. The reason may be due to isolation of proteins at different stage of maturation, different use of buffer extraction and method of isolation. From the reports of Trounson et al., 2001, it has been evidenced that in vitro mature human and bovine oocytes contain reduced protein content when compared with in vivo matured oocytes. In buffalo oocyte similar trend in our study was found, where mean protein content $(110.04 \pm 3.46)$ in in vitro matured oocyte was found lower than in vivo

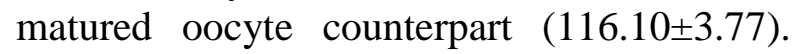
During the in vitro maturation of COCs number of cumulus cell gets increases accordingly protein content of these oocytes complex too increases (Wu et al., 1996; Cetica et al., 2001). But this may not be the sole reason behind it since, many other intrinsic factors also plays role. Gandolfi et al., 1998 documented that oocytes recovered from bovine calf ovaries, differ from those isolated from adult gonads in terms of energy metabolism, diameter and protein synthesis. Also the oocytes obtained from large follicle and small follicle differs in protein levels. Oocyte quality depends on many factors known and many still to be investigated where quality markers works to play (Mermillod et al., 2008). The amount of proteins present in zonapellucida play important role in oocyte structure, which came out to be approximately $13 \%$ in buffalo it may varies from species to species. However, it can be said that protein content in zona changes after maturation. Highest number $(3,763)$ of protein data set in buffalo oocyte is recently been reported (Chen et al., 2016), these data may differ since specific set of proteins (splicing regulating proteins) takes place in specific stage while other may be degraded at the same time (Fu et al., 2016). For instance, although human oocyte contains approximately 100ng of protein, only 450 proteins were recovered consistently (VirantKlun et al., 2016). Size of oocyte also determines the level of proteins in oocyte, which is shown to vary linearly in mice (Schultz and Wassarman, 1977). A study documented 132,127 number of peptide at GV stage and 185,643 number of peptide at MII stage (Wang et al., 2010). It can be related to our immature oocyte protein content and mature oocyte protein content. 
But the overall content of protein may differ due to more or less expressions of selected proteins according to stage of function. For a comparative view across the species, mean protein content of one cell stage embryo is reported in rabbit (160ng), rat (37ng) mouse (24ng) and pig (273 ng) (Morgan et al.,
1993). Sometimes it may happen that we obtain protein content but it may not reflect same when we visualize on gel. It may be due to different use of buffers and different method of isolation of proteins. So the protein content and composition varies in oocyte according to stage of maturation.

Table.1 Various buffalo oocyte groups from which levels of proteins were estimated

\begin{tabular}{|r|l|l|l|}
\hline S. No. & \multicolumn{1}{|c|}{ Oocyte Groups } & $\begin{array}{r}\text { Mean protein } \\
\text { content(ng/Oocyte) }\end{array}$ & Range(ng/Oocyte) \\
\hline 1. & Immature Zona free & $93.72 \pm 2.76^{\mathrm{a}}$ & $90-97$ \\
\hline $\mathbf{2 .}$ & Immature & $107.14 \pm 3.79^{\mathrm{b}}$ & $102-112$ \\
\hline $\mathbf{3 .}$ & In vitro mature & $110.04 \pm 3.46^{\mathrm{c}}$ & $105-114$ \\
\hline $\mathbf{4 .}$ & In vivo mature & $116.11 \pm 3.77^{\mathrm{c}}$ & $111-120$ \\
\hline
\end{tabular}

* Means having different superscripts differ significantly $(\mathrm{p}<0.05)$

Fig.1 Four groups of oocyte having four technical replicates, each technical replicate contains 500 oocytes

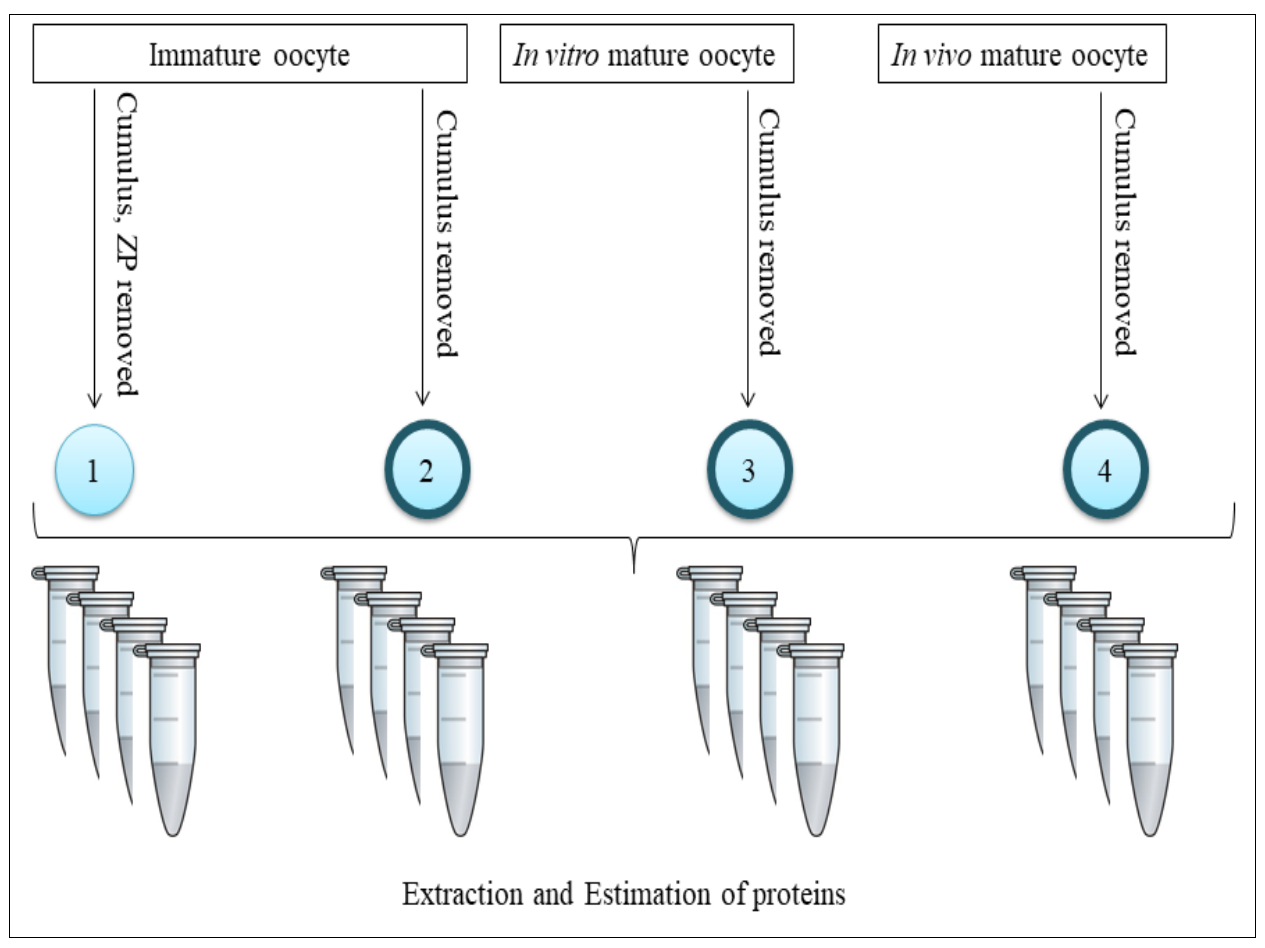


Fig.2 Cumulus removed zonapellucida enclosed oocyte and profile of proteins isolated from oocytes after electrophoresis on SDS-PAGE. Protein sample (10 $\mu \mathrm{g}$ proteins/lane) was loaded to confirm the integrity and accuracy of quantification by examining the band pattern. L1: (Marker)

L2 and L3 are proteins isolated from oocytes

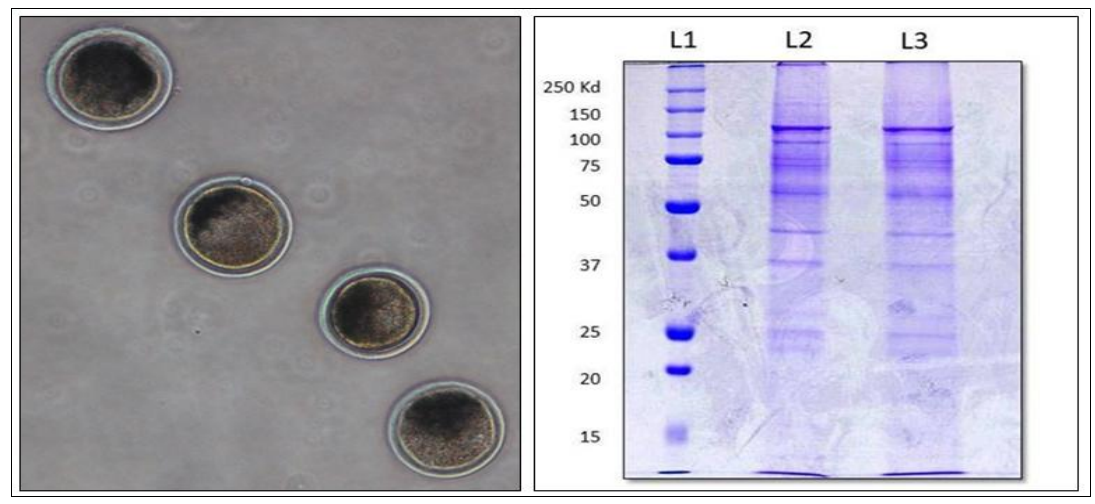

Fig.3 Quantified protein content are statistically designated in respective groups

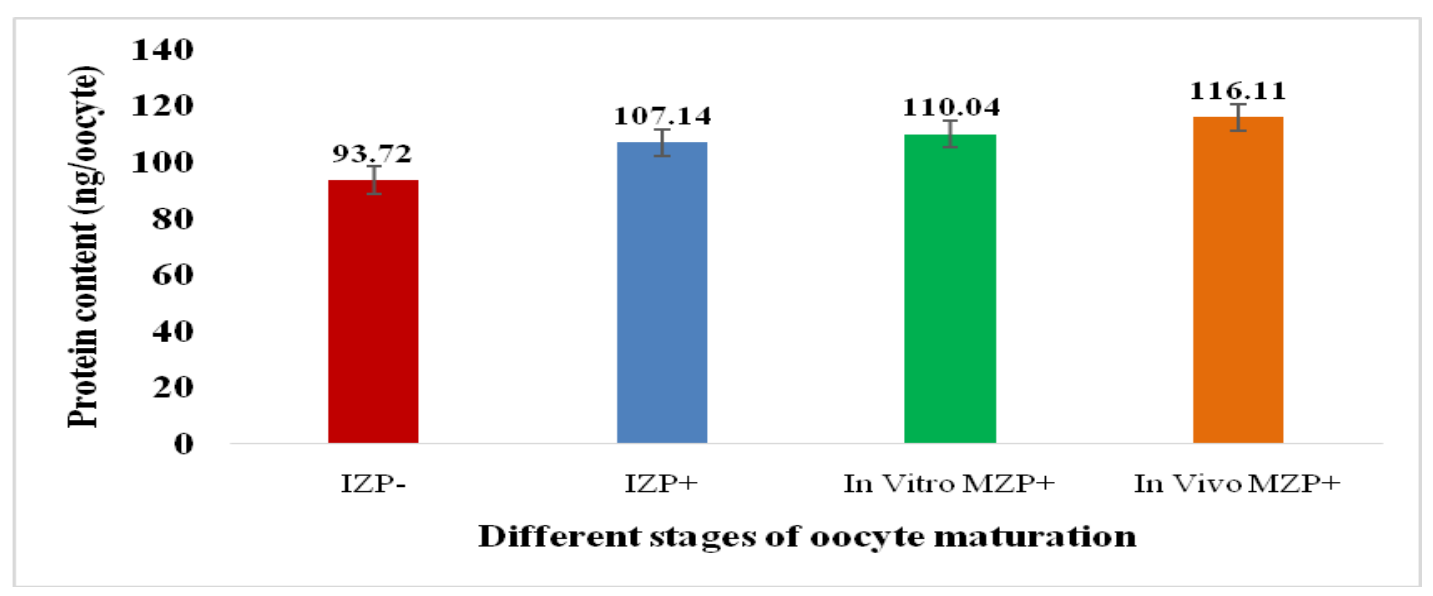

In conclusion, numerous factors govern the protein content in mammalian oocyte for instance, oocyte size, species breed, maternal nutritional, stress and several other intrinsic and external factors. The protein content and composition differs in perspective of different maturational stages of oocyte. From our report it is evident that comparative proteomic content at different stage of maturation may represent different metabolic state of mammalian oocyte. Protein content in zonapellucida may change its protein content since after maturation overall protein content and composition changes. It is clear that, in vitro matured oocyte contain reduced amount of protein when compared with in vivo matured oocytes. Our study depicts estimates of proteins which can be further used for setting experiments on buffalo oocyte proteomics and also in other species.

\section{References}

Bradford, M.M., 1976. A rapid and sensitive method for the quantitation of microgram quantities of protein utilizing the principle of protein-dye binding. Analytical biochemistry, 72(1-2): 248-254.

Cetica, P.D., Pintos, L.N., Dalvit, G.C. and Beconi, M.T., 2001. Antioxidant enzyme activity and oxidative stress in bovine oocyte in vitro maturation. IUBMB life, 51(1): 57-64.

Chen, L., Zhai, L., Qu, C., Zhang, C., Li, S., 
Wu, F., Qi, Y., Lu, F., Xu, P., Li, X. and Shi, D., 2016. Comparative proteomic analysis of buffalo oocytes matured in vitro using iTRAQ technique. Scientific reports, 6: 31795 .

Fu, Q., Liu, Z.F., Huang, Y.L., Lu, Y.Q. and Zhang, M., 2016. Comparative proteomic analysis of mature and immature oocytes of the swamp buffalo (Bubalus bubalis). International journal of molecular sciences, 17(1): 94.

Gandolfi, F., Milanesi, E., Pocar, P., Luciano, A.M., Brevini, T.A.L., Acocella, F., Lauria, A. and Armstrong, D.T., 1998.Comparative analysis of calf and cow oocytes during in vitro maturation. Molecular Reproduction and Development: Incorporating Gamete Research, 49(2): 168-175.

Grealy, M., Diskin, M.G. and Sreenan, J.M., 1996.Protein content of cattle oocytes and embryos from the two-cell to the elongated blastocyst stage at day 16 . Reproduction, 107(2): 229-233.

Herrick, J.R., Lane, M., Gardner, D.K., Behboodi, E., Memili, E., Blash, S., Echelard, Y. and Krisher, R.L., 2006. Metabolism, protein content, and in vitro embryonic development of goat cumulusoocyte complexes matured with physiological concentrations of glucose and L- lactate. Molecular Reproduction and Development: Incorporating Gamete Research, 73(2): 256-266.

Mermillod, P., Dalbiès- Tran, R., Uzbekova, S., Thélie, A., Traverso, J.M., Perreau, C., Papillier, P. and Monget, P., 2008. Factors affecting oocyte quality: who is driving the follicle? Reproduction in Domestic Animals, 43: 393-400.

Morgan, P.M. and Kane, M.T., 1993. Protein content of rabbit embryos: one cell to peri-implantation blastocyst. Reproduction, 97(1): 101-106.

Schultz, R.M. and Wassarman, P.M., 1977. Biochemical studies of mammalian oogenesis: protein synthesis during oocyte growth and meiotic maturation in the mouse. Journal of Cell Science, 24(1): 167-194.

Thompson, J.G., Sherman, A.N.M., Allen, N.W., McGowan, L.T. and Tervit, H.R., 1998. Total protein content and protein synthesis within pre- elongation stage bovine embryos. Molecular Reproduction and Development: Incorporating Gamete Research, 50(2): 139-145.

Trounson, A., Anderiesz, C. and Jones, G., 2001. Maturation of human oocytes in vitro and their developmental competence. Reproduction, 121(1): 5175.

Virant-Klun, I., Leicht, S., Hughes, C. and Krijgsveld, J., 2016.Identification of maturation-specific proteins by single-cell proteomics of human oocytes. Molecular \& Cellular Proteomics, 15(8), pp.26162627.

Wang, S., Kou, Z., Jing, Z., Zhang, Y., Guo, X., Dong, M., Wilmut, I. and Gao, S., 2010. Proteome of mouse oocytes at different developmental stages. Proceedings of the National Academy of Sciences, 107(41), pp.17639-17644.

Wu, B., Ignotz, G.G., Currie, W.B. and Yang, X., 1996.Temporal distinctions in the synthesis and accumulation of proteins by oocytes and cumulus cells during maturation in vitro of bovine oocytes. Molecular Reproduction and Development: Incorporating Gamete Research, 45(4), pp.560-565.

\section{How to cite this article:}

Raghvendra Kumar and Shalini Jaswal. 2020. Evaluation of Buffalo (Bubalus bubalis) Oocyte Protein Content at Different Stages of Maturation. Int.J.Curr.Microbiol.App.Sci. 9(10): 25112516. doi: https://doi.org/10.20546/ijcmas.2020.910.301 